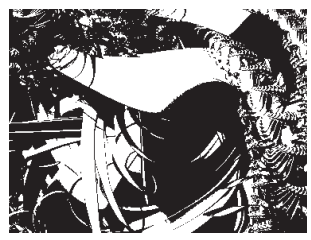

\title{
VJEŠTINA ČITANJA U RANOJ ADOLESCENCIJI: PROFILI UČENIKA
}

Barbara RONČEVIĆ ZUBKOVIĆ

Filozofski fakultet, Rijeka

UDK: 159.946.4-053.66

$028.7-053.66$

Izvorni znanstveni rad

Primljeno: 27. 4. 2009.

Cilj je ovog istraživanja bio ustanoviti mogu li se prepoznati homogene skupine, odnosno profili učenika s obzirom na uspješnost razumijevanja i brzinu čitanja, razvijenost rječnika, raspon kratkoročnoga i radnoga pamćenja te uspješnost primiene strategija čitanja. U istraživanju je sudjelovalo 186 učenika sedmih razreda (98 dječaka i 88 djevojčica). Ispitivalo se razumijevanje triju kraćih tekstova i mierila se brzina čitanja jednog od njih. Učenici su rješavali i test rječnika, upitnik strategijskoga čitanja, zadatke kratkoročnoga i radnoga pamćenja te se ispitivala uspiešnost prepoznavanja fokusnih riječi u rečenici i nepodudarnih rečenica u tekstu. Klasterskom analizom jasno su se izdvojila četiri profila učenika. Prvi klaster čine loši čitači koji na svim zadacima postižu ispodprosječne rezultate. Četvrti klaster čine dobri čitači koji postižu iznadprosječne rezultate na svim varijablama, osim u brzini čitanja, koja je prosječna. Drugi i treći klaster čine učenici s prosječnim razumijevanjem, brzinom čitanja i rječnikom te prosječnom uspješnošću prepoznavanja fokusnih riječi i nepodudarnih rečenica. Učenici iz drugoga klastera imaju značajno manji raspon kratkoročnoga i radnoga pamćenja od učenika iz trećega klastera, ali izvještavaju da češće od nị rabe strategije čitanja. Rezultati idu u prilog teorijama koje naglašavaju važnost upotrebe kompenzacijskih strategija, kojima se mogu nadvladati ograničenja u rasponu radnoga pamćenja (Walczyk i sur., 2001.; 2007.).

Ključne riječi: čitanje, razumijevanje, strategije, radno pamćenje fakultet u Rijeci, Odsjek za psihologiju, Slavka Krautzeka bb, 51000 Rijeka, Hrvatska. E-mail: roncevic@ffri.hr 
Vještina čitanja u velikoj mjeri određuje uspješnost u usvajanju znanja na svim obrazovnim razinama, od osnovne škole do fakulteta. Završni razredi osnovne škole čine period $u$ kojem se učenici susreću s novim predmetima i sve zahtjevnijom literaturom. Planiranje obrazovnih intervencija koje bi mogle pomoći adolescentima s problemima u razumijevanju pri čitanju (i kao posljedica toga vjerojatno i u školskom uspjehu) nije moguće bez razumijevanja komponenti i procesa uključenih u čitanje, kao i razvojnih specifičnosti vezanih za razvoj vještine čitanja.

Postoji nekoliko razina ili aspekata kroz koje možemo promatrati razvijenost čimbenika uključenih u aktivnost čitanja. Tako npr. Cain i Oakhill (2006.) smatraju da uspješno razumijevanje pri čitanju zahtijeva učinkovito usklađivanje različitih jezičnih vještina. Te se vještine odnose na leksičke vještine niže razine, koje uključuju dekodiranje, odnosno pretvaranje pisane riječi u fonološki kod, i bogatstvo rječnika; zatim na leksičke vještine na razini rečenice (npr. znanje o gramatičkoj strukturi) te konačno na vještine procesiranja teksta više razine, koje uključuju procese kao što su zaključivanje, integracija teksta, nadgledanje razumijevanja, ali i kapacitet radnoga pamćenja.

Problemi koji se javljaju pri čitanju u određenoj dobi mogu proizlaziti iz nerazvijenosti raznih aspekata ili razina. Rezultati istraživanja provedenih s učenicima početnih razreda osnovne škole pokazuju da kod većine djece s problemima pri čitanju problemi proizlaze iz fonološkoga procesiranja i/ili poteškoća na razini prepoznavanja riječi (Fletcher i sur., 1994.; Morris i sur., 1998.). Takvi rezultati idu u prilog modelima koji naglašavaju važnost fonoloških procesa za razumijevanje pri čitanju (npr. Shankweiler i Crain, 1986.). Međutim, i među čitačima početnicima postoji skupina djece koja ima adekvatne vještine dekodiranja i fonološkoga procesiranja, ali neadekvatno razumijevanje pri čitanju. Cain i Oakhill (2006.) uspoređivale su dvije skupine osmogodišnje djece s istom razinom dekodiranja, ali različitom uspješnošću razumijevanja, te su ustanovile da se skupine razlikuju u bogatstvu rječnika, verbalnom radnom pamćenju, sposobnosti strukturiranja priče, znanju o svrsi naslova tekstova, zaključivanju, integraciji teksta i nadgledanju razumijevanja.

Zanimljivo je, međutim, da većina istraživanja pokazuje kako i u višim razredima osnovne škole i u srednjoj školi postoje učenici koji još imaju problema s procesima koji bi do te dobi trebali biti automatizirani, kao što su dekodiranje, odnosno prepoznavanje riječi i fluentno čitanje (Rasinski i sur., 2005.). Pretpostavlja se da se stupanj vještine čitanja koji posjeduje odrasla osoba ne razlikuje mnogo od stupnja razvijeno- 
DRUŠ. ISTRAŽ. ZAGREB GOD. 20 (2011), BR. 1 (11 11$)$

STR. $189-210$

RONČEVIĆ ZUBKOVIĆ, B.: VJEŠTINA ČITANJA... sti vještine čitanja koju dijete dostigne početkom adolescencije, s obzirom na to da na kraju osnovne škole najčešće dolazi do usporavanja napretka u vještini čitanja (Francis i sur., 1996.). Dapače, čak i na fakultetskoj razini postoje značajne individualne razlike u brzini čitanja. Prosječan student čita oko 250 riječi u minuti, ali raspon varira od 150 do 400 riječi u minuti (Perfetti, 1985.). Zbog toga zabrinjava ako djeca koja pohađaju završne razrede osnovne škole još imaju problema s temeljnim vještinama čitanja, jer bi takvi problemi mogli postati stalni. Neki autori, naime, smatraju da su poteškoće u čitanju u toj dobi prilično otporne na edukacijske intervencije, s obzirom na to da su djeca prerasla ranu dob kada se vještine dekodiranja i prepoznavanja riječi najlakše usvajaju (Francis i sur., 1996.).

Međutim, čak i ako su vještine prepoznavanja riječi primjerene, mogu se javiti problemi s razumijevanjem teksta. Istraživanja provedena s učenicima viših razreda osnovne škole pokazuju da njih oko 10\% (u Velikoj Britaniji) ima problema s razumijevanjem pri čitanju, unatoč normalno razvijenim vještinama dekodiranja (Nation i Snowling, 1998.). Takva djeca imaju slabije vještine semantičkoga procesiranja, kao što su produkcija sinonima ili imenovanje riječi iz istih kategorija, a i kontekst rabe s manjom učinkovitosti. Imaju problema i s čitanjem riječi koje su rijetke i/ili imaju neuobičajen izgovor i tipično se čitaju uz pomoć semantike. Autori smatraju da ta djeca primarno imaju deficite unutar semantičkoga sustava, prije svega nedovoljno razvijen rječnik.

Posjedovanje adekvatnoga mentalnog rječnika jedan je od najvažnijih preduvjeta za uspješno razumijevanje teksta. Mjere kojima se ispituje bogatstvo rječnika, odnosno sposobnost sudionika da prepoznaju ili navedu značenje određene riječi, redovito se pokazuju kao ponajbolji samostalni prediktori razumijevanja pri čitanju (Cain i sur., 2004.b; Dixon i sur., 1988.; Kolić-Vehovec, 1994.; Yovanoff i sur., 2005.).

Međutim, Cain i suradnici su (2003., 2004.b) na temelju rezultata svojih istraživanja s djecom koja su imala poteškoće u razumijevanju teksta unatoč adekvatnim vještinama prepoznavanja riječi i fonološkog procesiranja zaključili da problemi u nekim slučajevima nisu povezani sa siromašnim rječnikom, nego u najvećoj mjeri proizlaze iz procesa i vještina više razine. Ti su procesi uključeni u konstrukciju reprezentacije značenja teksta i primarno se odnose na primjenu strategija čitanja. Pozitivna povezanost između učinkovite upotrebe raznih strategija čitanja i razumijevanja pri čitanju potvrđena je u nizu istraživanja (vidi Cromley, 2005.). Tako se pokazuje da učenici s neodgovarajućim razumijevanjem imaju problema u strategijskim ponašanjima, kao što su integracija teksta 
DRUŠ. ISTRAŽ. ZAGREB GOD. 20 (2011), BR. 1 (111)

STR. $189-210$

RONČEVIĆ ZUBKOVIĆ, B. VJEŠTINA ČITANJA... i zaključivanje (Cain i sur., 2001.) te procesiranje anaforičkih izraza i nadgledanje razumijevanja (Ehrlich i sur., 1999.), unatoč učinkovitu fonološkom procesiranju i prepoznavanju riječi.

Postoji nekoliko pretpostavki o tome što je primarni uzrok takvih problema. Jedna je mogućnost da ta djeca imaju neadekvatno opće znanje o temi, pa zbog toga ne mogu donijeti primjerene zaključke i integrirati tekst. No neka istraživanja (Cain i sur., 2001.) upozoravaju na to da djeca s lošim razumijevanjem stvaraju manje zaključaka, unatoč tome što posjeduju dovoljno znanja da bi ih mogli stvarati. Druga je mogućnost da se vještine više razine oslanjaju na resurse radnoga pamćenja, pa da deficiti u integraciji i zaključivanju proizlaze iz maloga raspona radnoga pamćenja.

Naime, stvaranje reprezentacije teksta zahtijeva stalno ažuriranje modela teksta na temelju upravo pročitanih ideja, koje se trebaju integrirati u postojeću reprezentaciju. Pretpostavlja se da je, za razliku od kratkoročnoga pamćenja, koje je bitno za razumijevanje jer ima ulogu u zadržavanju površinskih kodova, kao što su konkretne riječi i rečenice, radno pamćenje važno za izgradnju mentalnoga modela teksta (Engle i sur., 1992.). Pri čitanju, osobe s većim rasponom radnoga pamćenja imaju veću mogućnost održavanja i kombiniranja jedinica značenja teksta u radnom pamćenju, istodobno primjenjujući strategijska ponašanja i povezujući sadržaj teksta s prijašnjim znanjem. Takvo učinkovito procesiranje rezultira boljim razumijevanjem, odnosno većim uspjehom u donošenju zaključaka o tekstu. Problemi s donošenjem zaključaka o značenju riječi kod djece s malim rasponom radnoga pamćenja posebno su izraženi u situacijama kada je kontekst, odnosno dio teksta u kojem se objašnjava značenje riječi, udaljen od same riječi (Cain i sur., 2003., 2004.b).

Swanson i suradnici (2006.) pokazali su da kratkoročno i radno pamćenje $u$ ranoj adolescenciji imaju važnu ulogu u razlikovanju djece s dobrim i lošim razumijevanjem. Međutim, čini se da razlike u radnom pamćenju između grupa djece $s$ različitim razumijevanjem ne mogu potpuno objasniti njihovu različitu razinu uspjeha na zadacima koji ispituju nadgledanje razumijevanja, poput otkrivanja pogrešaka. Naime, razlika između grupa i dalje postoji i kada se radno pamćenje uključi u analizu kao kovarijat (Oakhill i sur., 2005.). Cain i suradnici (2004.a) također su ustanovili da iako se radno pamćenje pokazalo jakim prediktorom razumijevanja, druge su varijable, poput nadgledanja razumijevanja, objasnile dodatan dio varijance razumijevanja pri čitanju. Moguće je da problemi te djece proizlaze, osim iz deficita radnoga pamćenja, i iz neznanja ili neučinkovitosti u upotrebi strategija čitanja. Tomu u prilog idu i rezultati istraživanja Cain i suradnika (2001.), koji su analizom dječjih pogrešaka u stvaranju zaključaka o tekstu 
DRUŠ. ISTRAŽ. ZAGREB GOD. 20 (2011), BR. 1 (111)

STR. $189-210$

RONČEVIĆ ZUBKOVIĆ, B.: VJEŠTINA ČITANJA... ustanovili da je najvjerojatniji uzrok problema u stvaranju zaključaka kod djece s lošim razumijevanjem nesposobnost odabira informacije koja je nužna za stvaranje zaključka.

Strategije čitanja rijetko se eksplicitno poučavaju, premda neka istraživanja pokazuju da ako osoba učinkovito rabi strategije čitanja, poput pauziranja, pogledavanja unatrag i ponovnoga čitanja teksta, može nadoknaditi neprimjerene vještine prepoznavanja riječi (Walczyk i sur., 2001;; Walczyk i Griffith-Ross, 2007.), ali i ograničeni kapacitet radnoga pamćenja (Walczyk i sur., 2007.). Nalaz je posebno važan kada se uzme $u$ obzir da na kraju osnovne škole dolazi do stagnacije u uratku na zadacima kratkoročnoga i radnoga pamćenja (Gathercole, 1999.; Siegel, 1994.). Tako bi rezultati na tim zadacima u ranoj adolescentskoj dobi mogli upućivati na kapacitete koji će ostati stabilni do odrasle dobi, pa je važno ustanoviti postoje li načini za nadvladavanje tih ograničenih resursa kako bi se omogućilo učinkovitije razumijevanje pri čitanju.

Kako bi se dobio bolji uvid u ulogu pojedinih čimbenika u razumijevanju pri čitanju, ali i mogle planirati odgovarajuće obrazovne intervencije za učenike završnih razreda osnovne škole, važno je ustanoviti možemo li razlikovati skupine adolescenata s obzirom na njihov obrazac razvijenosti čimbenika važnih za razumijevanje pri čitanju. Tako je cilj ovog istraživanja ustanoviti postoje li homogene skupine učenika s obzirom na uspješnost razumijevanja i brzinu čitanja, razvijenost rječnika, raspon kratkoročnoga i radnoga pamćenja te uspješnost primjene strategija čitanja. Na temelju navedenih istraživanja i teorijskih pretpostavki možemo zaključiti da će postojati skupine s različitim stupnjem razumijevanja teksta te da poteškoće mogu proizlaziti iz neadekvatnih vještina niže razine, ograničenosti kapaciteta kognitivnih resursa, poput radnoga pamćenja, ili neučinkovite upotrebe strategija čitanja.

\section{METODA}

\section{Sudionici}

U istraživanju je sudjelovalo 186 učenika sedmih razreda triju osnovnih škola u Rijeci. U istraživanje nisu uključeni učenici koji nastavu pohađaju po prilagođenom programu. Uzorak je činilo 98 dječaka i 88 djevojčica, raspona dobi od 13 godina i 2 mjeseca do 14 godina i 3 mjeseca.

\section{Instrumenti}

\section{Razumijevanje pri čitanju}

Razumijevanje pri čitanju ispitivalo se trima kratkim tekstovima. Nakon čitanja svakog od tekstova sudionici su odgovarali na tri pitanja otvorenoga tipa i tri pitanja višestrukog izbora s 
DRUŠ. ISTRAŽ. ZAGREB GOD. 20 (2011), BR. $1(111)$

STR. $189-210$

RONČEVIĆ ZUBKOVIĆ, B. VJEŠTINA ČITANJA... četiri ponuđena odgovora, čija je primjerenost provjerena $u$ predistraživanju. Dva su pitanja višestrukog izbora u predistraživanju bila prelagana, pa su preformulirana tako da su ponuđeni izbori promijenjeni. Distribucija odgovora na nova pitanja je zadovoljavala. Tekstovi su pri odgovaranju bili dostupni učenicima. Točan odgovor na pitanja višestrukog izbora nosio je jedan bod, dok je točan odgovor na pitanja otvorenoga tipa nosio dva, a polovičan jedan bod. Na svakom je tekstu sudionik mogao dobiti maksimalno 9 bodova, pa je maksimalan rezultat na zadatku razumijevanja mogao biti 27.

\section{Brzina čitanja teksta}

Brzina čitanja operacionalizirana je kao ukupno vrijeme $u$ sekundama potrebno za čitanje trećega teksta kojim se ispitivalo razumijevanje. Prije nego što je dobio pisanu verziju teksta s pitanjima, sudionik je čitao tekst s ekrana računala. Tekst se pojavljivao redak po redak. Kada bi pročitao redak teksta, sudionik je kliknuo tipkom miša kako bi se pojavio sljedeći redak.

\section{Rječnik}

Test rječnika adaptacija jest Hershelova (1963.) testa, što su ga s engleskog na slovenski jezik preveli Zorman i Žagar (1974., u Toličič i Zorman, 1977.), a nedavno je sa slovenskog jezika preveden na hrvatski jezik te je provjerena njegova valjanost i pouzdanost (Cronbach-alfa =0,83) (Didović i Kolić-Vehovec, 2009.). Test se sastoji od 40 zadataka višestrukog izbora s ponuđenih pet opcija (npr. Bez dobrih rezultata znači: $A$ štetan $B$ trajan $C$ indiskretan $D$ neučinkovit $E$ učinkovit). Za svaki točan odgovor sudionik dobiva po jedan bod, pri čemu je maksimalan broj bodova 40 . Vrijeme rješavanja testa ograničeno je na 10 minuta.

\section{Percipirana upotreba strategija čitanja}

Upitnik strategijskoga čitanja (USČ, Kolić-Vehovec i Bajšanski, 2001.) mjeri percipiranu učestalost upotrebe strategija čitanja na skali Likertova tipa od pet stupnjeva (1 - nikada to ne činim do 5 - uvijek to činim). Upitnik se sastoji od 31 tvrdnje koje su raspoređene $\mathrm{u}$ tri podljestvice: podljestvicu strategija aktivnoga razumijevanja (16 tvrdnji; Cronbach-alfa $=0,82$ ), koja uključuje tvrdnje koje se odnose na aktivnu konstrukciju značenja tijekom čitanja; podljestvicu strategija nadgledanja i regulacije ( 9 tvrdnji; Cronbach-alfa $=0,84$ ), koja sadrži tvrdnje koje se odnose na provjeravanje razine razumijevanja te na procese regulacije tijekom čitanja koji se primjenjuju ako razina razumijevanja ne zadovoljava; podljestvicu strategija zaključivanja (6 tvrdnji; Cronbach-alfa $=0,78$ ), koja sadrži tvrdnje koje se odnose na predviđanje budućega tijeka priče i stvaranje predodžbi o sadržaju priče. 
DRUŠ. ISTRAŽ. ZAGREB GOD. 20 (2011), BR. 1 (111)

STR. $189-210$

RONČEVIĆ ZUBKOVIĆ, B.: VJEŠTINA ČITANJA...

\section{Prepoznavanje nepodudarnih rečenica}

Zadatak otkrivanja nepodudarnih rečenica upotrijebljen je kao direktna mjera strategijskoga čitanja. Zadatak zahtijeva od sudionika nadgledanje razumijevanja (Kolić-Vehovec i Bajšanski, 2006.), odnosno vrednovanje teksta i donošenje odluke o tome koji su dijelovi teksta važni, a koji nisu (Williams i sur., 1981.).

U tom su zadatku sudionici u tekstu koji se sastojao od šest ulomaka trebali podcrtati semantički nepodudarne rečenice, odnosno rečenice za koje su smatrali da nisu dio ulomka. Rezultat na zadatku predstavlja ukupan broj točno otkrivenih nepodudarnih rečenica, pri čemu maksimalni rezultat iznosi šest, s obzirom na to da je u svaki ulomak ubačena po jedna nepodudarna rečenica. Zadatak je u ranijim istraživanjima pokazao zadovoljavajuću diskriminativnost te je bio značajan prediktor razumijevanja pri čitanju (Kolić-Vehovec i Bajšanski, 2006.).

\section{Verbalno radno pamćenje}

Raspon verbalnoga radnog pamćenja ispitivan je na računalima. Od učenika se tražilo da naglas čita rečenicu po rečenicu koje su se pojavljivale na ekranu računala. Pošto je učenik pročitao rečenicu, trebao je kursorom označiti riječ u rečenici za koju smatra da je najvažnija za razumijevanje rečenice. Kad je učenik označio riječ, pojavila se nova rečenica koju je odmah trebao početi čitati. Nakon svakoga od devet blokova rečenica od sudionika se tražilo da se pokuša po redu dosjetiti riječi koje je označio. Blokovi rečenica u zadatku imali su od tri do pet rečenica. Raspon verbalnoga radnog pamćenja predstavljao je ukupan broj riječi kojih se sudionik točno dosjetio. Svaka riječ donosila je jedan bod, a kako je u zadatku bilo 36 rečenica, maksimalan rezultat mogao je iznositi 36 bodova.

U zadatku radnoga pamćenja provjeravala se i učinkovitost određivanja fokusne riječi, odnosno riječi najvažnije za razumijevanje rečenice. Uspješno određivanje fokusne riječi upućuje na to da su sudionici pokazali sposobnost analize rečenice i strategijsko ponašanje s obzirom na to da je fokusna riječ ona riječ važna za razumijevanje i integraciju rečenice. Ako je sudionik označio riječ koja je u predistraživanju bila određena kao fokusna, dodijeljen mu je jedan bod. Maksimalan broj bodova koje je sudionik mogao dobiti bio je 36 .

Predistraživanje u kojem su određene fokusne riječi provedeno je prema smjernicama navedenim $u$ istraživanju Osake i sur. (2002.). Studenti psihologije trebali su u nizu od 70 ponuđenih rečenica odrediti riječi koje su najvažnije za razumijevanje svake pojedine rečenice. Sve fokusne riječi koje su studenti odredili bile su imenice. One su se nalazile na različitim mjestima u rečenici te su bile različite čestoće (prema Moguš i sur., 1999.). U zadatak radnoga pamćenja uvršteno je 36 rečenica, kod kojih je slaganje studenata o fokusnoj riječi bilo $90 \%$ ili više. 
DRUŠ. ISTRAŽ. ZAGREB GOD. 20 (2011), BR. $1(111)$

STR. $189-210$

RONČEVIĆ ZUBKOVIĆ, B. VJEŠTINA ČITANJA...
Pošto su završili zadatak, sudionici su trebali navesti strategije kojima su se služili za upamćivanje riječi u zadatku. Prilikom kodiranja odgovori su raspoređeni u tri kategorije: strategije površinskoga procesiranja (ponavljanje riječi ili čitavih rečenica); strategije dubinskoga kodiranja (smišljanje priče od riječi koje je trebalo upamtiti, dovođenje riječi u vezu s vlastitim životom, vizualizacija riječi) te treća kategorija koja je uključivala odgovore koji su pokazivali da sudionik nije rabio strategije pri upamćivanju.

\section{Verbalno kratkoročno pamćenje}

Raspon verbalnoga kratkoročnog pamćenja, poput raspona radnoga pamćenja, ispitivan je na računalima. U ovom se zadatku od učenika tražilo da pažljivo naglas čita riječ po riječ koje su se pojavljivale na ekranu računala. Pošto bi sudionik pročitao riječ, trebao ju je kursorom označiti, nakon čega bi se pojavila nova riječ. Nakon svakoga od devet blokova riječi od sudionika se tražilo da se pokuša dosjetiti riječi redom kojim su bile prikazane na ekranu. Sve su prikazane riječi bile imenice, slične duljine i čestoće kao fokusne riječi u zadatku radnoga pamćenja, $\mathrm{s}$ tim da je $\mathrm{u}$ svakom bloku dodana po jedna riječ kako bi se zadatak otežao, pa je ukupno bilo 45 rečenica. Raspon verbalnoga kratkoročnog pamćenja predstavljao je ukupan broj riječi kojih se sudionik točno dosjetio. Svaka je točna riječ donosila jedan bod, tako da je maksimalan rezultat mogao iznositi 45 bodova.

Cijeli je postupak bio sličan onom u zadatku radnoga pamćenja, ali zadaci namijenjeni mjerenju uspješnosti pripadaju različitim procesnim sustavima. Pretpostavlja se da zadaci radnoga pamćenja ispituju učinkovitost središnjeg izvršitelja u Baddeleyevu modelu, a zadaci kratkoročnoga pamćenja zahtijevaju aktivaciju fonološke petlje i ispituju kapacitet pasivne pohrane (Engle i sur., 1992.).

\section{Postupak}

Ispitivanje je provedeno u dva dijela. Prvi je dio ispitivanja bio grupni, $u$ trajanju od jednoga školskog sata i provodio se $u$ razrednim odjelima. $U$ tom su dijelu istraživanja učenici ispunjavali test rječnika, upitnik strategijskoga čitanja i zadatak otkrivanja nepodudarnih rečenica. Učenici su odgovarali i na pitanja kojima se ispitivalo razumijevanje dvaju tekstova. Drugi se dio ispitivanja provodio sa svakim učenikom pojedinačno, na računalu, $\mathrm{u}$ tihoj prostoriji u školi. Svaki je učenik najprije rješavao zadatak radnoga pamćenja. Nakon toga čitao je treći tekst za ispitivanje razumijevanja, pri čemu se mjerila i brzina čitanja, pa je pismeno odgovarao na pitanja kojima se ispitivalo razumijevanje. Na kraju je rješavao zadatak 
kratkoročnoga pamćenja. Prije početka ispitivanja učenici i roditelji obaviješteni su o razlozima i načinu ispitivanja, kao i o mogućnosti odustajanja.

Kako bi se ispitalo postoje li specifične skupine čitača s obzirom na brzinu čitanja i uspješnost razumijevanja teksta te razvijenost čimbenika relevantnih za vještinu čitanja, upotrijebljena je K-means metoda klasterske analize. Kako su rezultati prikupljeni na raznim skalama, prethodno su standardizirani, odnosno pretvoreni u z-vrijednosti. Viša z-vrijednost upućuje na bolji uradak u zadatku. S obzirom na to da je uobičajeno testirati nekoliko klasterskih rješenja, testirana su rješenja sa tri, četiri i pet klastera.

U troklasterskom rješenju prvi klaster $(\mathrm{N}=39)$ čine loši čitači, odnosno učenici koji na većini zadataka postižu ispodprosječne rezultate. Imaju ispodprosječno razumijevanje, ispodprosječnu brzinu čitanja, siromašan rječnik, ispodprosječno su uspješni u određivanju fokusnih riječi i nepodudarnih rečenica te imaju ispodprosječni raspon kratkoročnoga i radnoga pamćenja. Na podljestvicama aktivnoga razumijevanja i regulacije upitnika strategijskoga čitanja postižu prosječne rezultate, a na podljestvici zaključivanja nešto ispodprosječne. Drugi klaster $(N=49)$ čine prosječni čitači, odnosno učenici koji imaju prosječne rezultate na svim zadacima, ali na svim podljestvicama upitnika strategijskoga čitanja postižu ispodprosječne rezultate. Najveći, treći, klaster $(\mathrm{N}=90)$ čine dobri čitači, odnosno učenici koji postižu prosječne ili iznadprosječne rezultate na svim varijablama, a od drugoga klastera značajno se razlikuju po razumijevanju, bogatstvu rječnika i percipiranoj upotrebi strategija te granično po označavanju nepodudarnih rečenica, pri čemu postižu bolje rezultate.

U četveroklasterskom rješenju (Slika 1) prvi je klaster gotovo identičan kao u troklasterskom, odnosno čine ga loši čitači, odnosno učenici $(\mathrm{N}=26)$ koji na svim zadacima postižu ispodprosječne rezultate, premda imaju prosječnu percipiranu upotrebu strategija aktivnoga razumijevanja i regulacije. Drugi $(\mathrm{N}=49)$ i treći klaster $(\mathrm{N}=46)$ čine učenici s prosječnim razumijevanjem i brzinom čitanja, prosječnim rječnikom te prosječnom uspješnošću prepoznavanja fokusnih riječi i nepodudarnih rečenica. Te dvije skupine ne razlikuju se u navedenim varijablama, ali se razlikuju u rasponu pamćenja i u percipiranoj upotrebi strategija čitanja. Učenici iz trećega klastera imaju značajno veći raspon kratkoročnoga i radnoga pamćenja, ali percipiraju da se rjeđe koriste strategijama čitanja od učenika iz drugoga klastera. Četvrti klaster $(\mathrm{N}=57)$ čine dobri čitači, odnosno učenici koji postižu iznadprosječne rezultate na svim varijablama, osim u brzini čitanja, koja je prosječna. 
DRUŠ. ISTRAŽ. ZAGREB GOD. 20 (2011),

BR. $1(111)$

STR. 189-210

RONČEVIĆ ZUBKOVIĆ, B.: VJEŠTINA ČITANJA...

\section{$\rightarrow$ SLIKA 1}

Profili učenika s obzirom na razvijenost vještine čitanja: četveroklastersko riešenje

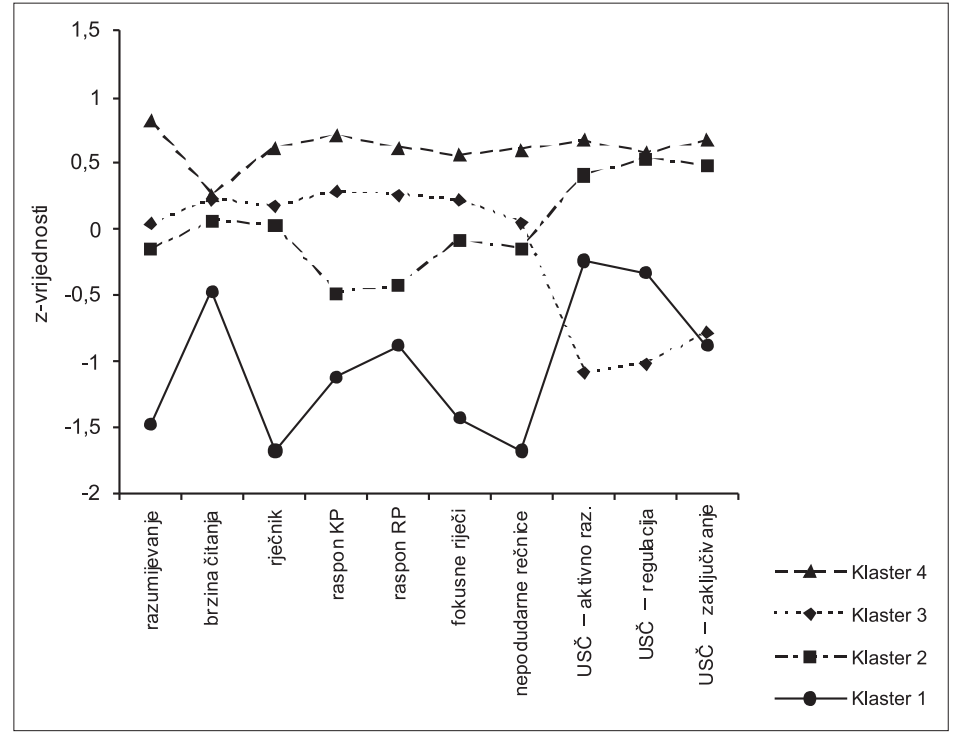

U peteroklasterskom rješenju prvi i peti klaster i dalje ostaju relativno stabilni, pri čemu prvi klaster čine učenici s ispodprosječnim rezultatima, a peti klaster oni s iznadprosječnim rezultatima na svim varijablama. Drugi klaster veoma je sličan trećem klasteru iz četveroklasterskoga rješenja, dok su dva nova klastera nastala u većoj mjeri cijepanjem drugoga klastera iz četveroklasterskoga rješenja, pri čemu eksternalna heterogenost novonastalih klastera nije velika i teško se može prepoznati jasan obrazac rezultata.

Četveroklastersko rješenje čini se najprihvatljivijim rješenjem s obzirom na to da je informativnije od troklasterskoga, a dobiveni se profili jasno diferenciraju. Efekti pripadnosti klasteru na razumijevanje teksta, vrijeme čitanja teksta, rječnik, raspon kratkoročnoga i radnoga pamćenja, uspješnost u određivanju fokusnih riječi i nepodudarnih rečenica te na percipiranu upotrebu strategija čitanja testirani su nizom jednosmjernih analiza varijance (Tablica 1 ).

Kako bi se ustanovilo jesu li razlike u rasponu radnoga pamćenja posljedica upotrebe strategija upamćivanja ciljnih riječi u zadatku radnoga pamćenja, jednosmjernom analizom varijance provjereno je razlikuju li se skupine s različitom upotrebom strategija $u$ rasponu radnoga pamćenja. Ustanovljeno je da je efekt upotrebe strategija na raspon radnoga pamćenja značajan $(\mathrm{F}(2,176)=4,52, \mathrm{p}<0,05)$. Učenici koji nisu rabili strategije za upamćivanje riječi imali su niži raspon radnoga pamćenja $(\mathrm{M}=19,22, \mathrm{SD}=3,93)$ od učenika koji su rabili strategije površinskoga $(\mathrm{M}=21,08 ; \mathrm{SD}=3,81)$ ili dubinskoga procesiranja $(\mathrm{M}=21,45 ; \mathrm{SD}=4,50)$. Između dvije skupine koje su koristile strategijsko ponašanje za upamćivanje riječi nije bilo statistički značajne razlike. 


\begin{tabular}{|c|c|c|c|c|c|c|}
\hline & & Klaster 1 & Klaster 2 & Klaster 3 & Klaster 4 & $\mathrm{~F}(3,174)$ \\
\hline \multirow[t]{2}{*}{ Razumijevanje teksta } & M & 9,65234 & 16,1014 & 17,0914 & 20,98123 & \multirow[t]{2}{*}{$63,17^{* * *}$} \\
\hline & SD & 3,69 & 3,97 & 3,85 & 2,64 & \\
\hline \multirow[t]{2}{*}{ Vrijeme čitanja } & M & 190,3234 & 151,651 & 139,421 & 137,361 & \multirow[t]{2}{*}{$20,39 * * *$} \\
\hline & SD & 49,52 & 30,77 & 24,62 & 22,02 & \\
\hline \multirow[t]{2}{*}{ Rječnik } & $\mathrm{M}$ & 18,92234 & 29,6314 & 30,6314 & 33,39123 & \multirow[t]{2}{*}{$67,51^{* * *}$} \\
\hline & SD & 6,42 & 4,94 & 3,52 & 3,07 & \\
\hline \multirow[t]{2}{*}{$\mathrm{KP}$ - raspon } & M & 27,27234 & 30,35134 & 34,07124 & 36,12123 & \multirow[t]{2}{*}{$44,58^{* * *}$} \\
\hline & SD & 4,78 & 3,56 & 3,36 & 3,39 & \\
\hline \multirow[t]{2}{*}{$R P$ - raspon } & $\mathrm{M}$ & 17,00234 & 18,82134 & 21,59124 & 23,02123 & \multirow[t]{2}{*}{$24,72^{* * *}$} \\
\hline & SD & 3,32 & 3,59 & 3,96 & 2,81 & \\
\hline \multirow[t]{2}{*}{ Fokusne riječi } & $\mathrm{M}$ & 20,42234 & 28,5314 & 30,2614 & 32,35123 & \multirow[t]{2}{*}{$40,67^{* * *}$} \\
\hline & SD & 6,24 & 5,3 & 4,73 & 2,88 & \\
\hline \multirow[t]{2}{*}{ Nepodudarne rečenice } & $\mathrm{M}$ & 2,73234 & 3,8114 & 4,1314 & 4,95123 & \multirow[t]{2}{*}{$19,05^{* * *}$} \\
\hline & SD & 1,66 & 1,27 & 1,36 & 0,93 & \\
\hline \multirow[t]{2}{*}{ USČ - aktivno raz. } & $\mathrm{M}$ & 41,54234 & 49,7113 & 30,89124 & 52,8913 & \multirow[t]{2}{*}{$56,22^{* * *}$} \\
\hline & SD & 11,76 & 8,32 & 7,14 & 9,88 & \\
\hline \multirow[t]{2}{*}{ USČ - regulacija } & $\mathrm{M}$ & 25,77234 & 31,8013 & 20,91124 & 32,0513 & \multirow[t]{2}{*}{$59,00^{* * *}$} \\
\hline & SD & 6,71 & 4,56 & 4,66 & 5,24 & \\
\hline \multirow[t]{2}{*}{ USČ - zaključivanje } & $\mathrm{M}$ & 15,7724 & 23,6113 & 16,3924 & 24,7513 & \multirow[t]{2}{*}{$56,92^{* * *}$} \\
\hline & $\mathrm{SD}$ & 5,44 & 2,95 & 4,78 & 3,52 & \\
\hline
\end{tabular}

*** $\mathrm{p}<0,001$. Napomena: indeksi kod aritmetičkih sredina označuju značajne razlike među grupama (Newman-Keulsov post-hoc test)

(1) TABLICA 1

Razlike među klasterima u razumijevanju teksta, vremenu čitanja teksta, rječniku, rasponu kratkoročnoga i radnoga pamćenja, prepoznavanju fokusnih riječi i nepodudarnih rečenica te percipiranol upotrebi strategija

TABLICA 2 Frekvencija učenika u pojedinim klasterima $s$ obzirom na upotrebu strategiija upamćivanja riječi u zadatku radnoga pamćenja
U Tablici 2 prikazana je frekvencija učenika u svakom klasteru s obzirom na upotrebu strategija upamćivanja riječi u zadatku radnoga pamćenja. U svim je klasterima najveći postotak učenika rabio strategije površinskoga, a najmanji postotak strategije dubinskoga procesiranja. Ipak, u prvom klasteru (loši čitači) podjednak je postotak učenika koji se služio strategijama i onih koji se strategijama nisu služili. U ostalim se klasterima većina učenika $(70 \%-77 \%)$ koristila strategijama.

\begin{tabular}{llll}
\hline & $\begin{array}{l}\text { Strategije } \\
\text { površinskoga } \\
\text { procesiranja }\end{array}$ & $\begin{array}{l}\text { Strategije } \\
\text { dubinskoga } \\
\text { procesiranja }\end{array}$ & Bez strategija \\
\hline Klaster 1 & 10 & 4 & 12 \\
$\%$ unutar klastera & 38,5 & 15,4 & 46,2 \\
Klaster 2 & 33 & 4 & 12 \\
$\%$ unutar klastera & 67,3 & 8,2 & 24,5 \\
Klaster 3 & 24 & 8 & 14 \\
$\%$ unutar klastera & 52,2 & 17,4 & 30,4 \\
Klaster 4 & 32 & 12 & 13 \\
$\%$ unutar klastera & 56,1 & 21,1 & 22,8 \\
Ukupno & 99 & 28 & 51 \\
$\%$ & 55,6 & 15,7 & 28,7 \\
\hline
\end{tabular}


DRUŠ. ISTRAŽ. ZAGREB BR. $1(111)$

STR. $189-210$

RONČEVIĆ ZUBKOVIĆ, B. VJEŠTINA ČITANJA...

$\rightarrow$ TABLICA 3

Frekvencija diečaka i djevojčica u pojedinim klasterima GOD. 20 (2011),

Kako bi se provjerilo postoje li razlike u spolnoj strukturi klastera, hi-kvadrat testom ispitano je postoji li statistički značajna razlika u broju dječaka i djevojčica u svakom od dobivenih klastera. Rezultati pokazuju da jedino u drugom klasteru nema statistički značajne razlike $\mathrm{u}$ broju djevojčica i dječaka. Prvi i treći klaster u većoj mjeri čine dječaci, dok četvrti klaster broji dvostruko više djevojčica (Tablica 3).

\begin{tabular}{llll}
\hline & Dječaci & Djevojčice & $\chi^{2}$ \\
\hline Klaster 1 & 20 & 6 & $7,54^{* *}$ \\
Klaster 2 & 22 & 27 & 0,51 \\
Klaster 3 & 30 & 16 & $4,26^{*}$ \\
Klaster 4 & 19 & 38 & $6,33^{*}$ \\
Ukupno & 91 & 87 &
\end{tabular}

${ }^{*} \mathrm{p}<0,05 ;{ }^{* *} \mathrm{p}<0,01$

\section{RASPRAVA}

Rezultati ovog istraživanja pokazuju da se na temelju klasterske analize mogu jasno izdvojiti četiri profila, odnosno klastera, učenika sedmih razreda: loši čitači, dobri čitači te dvije skupine koje čine prosječni čitači.

Loši čitači čine prvi klaster i obuhvaćaju oko 15\% uzorka. To su učenici koji imaju najlošije razumijevanje, najsporije čitaju, imaju najsiromašniji rječnik, najmanje raspone kratkoročnoga i radnoga pamćenja te najmanju učinkovitost u označavanju fokusnih riječi i nepodudarnih rečenica. U svim se navedenim varijablama značajno razlikuju od učenika iz svih ostalih skupina. Percipirana je upotreba strategija čitanja u toj skupini također ispodprosječna. Neki autori (Morris i sur., 1998.; Shankweiler i Crain, 1986.) smatraju da problemi s razumijevanjem kod većine čitača primarno proizlaze iz deficita $\mathrm{u}$ fonološkom procesiranju, bilo da se ono odnosi na fonološku svjesnost ili sposobnost zadržavanja informacija u fonološkoj petlji. S druge strane, Nation i Snowling (1998.) ustanovile su da dio djece unatoč normalnom fonološkom procesiranju i dekodiranju ima problema sa zadacima koji zahtijevaju semantičko procesiranje, uključujući i zadatke radnoga pamćenja, koji su semantički zahtjevni. Pretpostavljaju da problemi kod te djece proizlaze iz deficita semantičkoga sustava, pri čemu najvažniju ulogu ima siromašan rječnik. Cain i sur. (2003., 2004.b) ustanovili su pak da određen dio djece s problemima $\mathrm{u}$ razumijevanju nema problema s fonološkim procesiranjem i prepoznavanjem riječi, ali ni s rječnikom, već da problemi kod njih proizlaze iz procesa i vještina više razine, kao što su integracija teksta, zaključivanje, procesiranje anaforičkih izraza i nadgledanje razumijevanja. 
DRUŠ. ISTRAŽ. ZAGREB GOD. 20 (2011), BR. 1 (111)

STR. $189-210$

RONČEVIĆ ZUBKOVIĆ, B.: VJEŠTINA ČITANJA...
U ovom istraživanju loši čitači imaju problema u svim ispitivanim varijablama, a taj klaster učenika ostaje stabilan i ne dijeli se ni kada se poveća broj klastera u analizi, što upućuje na to da ti učenici čine homogenu skupinu koja pokazuje kombinirane deficite. Zbog toga se uzrok problema s razumijevanjem pri čitanju ne može objasniti isključivo jednom teorijom, nego je očito riječ o složenijim problemima.

Cromley je (2005.) u svojem istraživanju također ustanovila da između učenika s lošim i dobrim razumijevanjem postoje statistički značajne razlike $\mathrm{u}$ brojnim varijablama: rječniku, brzini čitanja, prijašnjem znanju, zaključivanju i strategijama čitanja. Slične rezultate dobili su i Swanson i Alexander (1997.), koji su ustanovili da se vješti čitači i djeca s nesposobnosti učenja razlikuju u svim aspektima čitanja, od fonološkoga procesiranja preko rječnika i raspona radnoga pamćenja do metakognicije. Autori smatraju da u podlozi tih problema leži ograničen sustav radnoga pamćenja, koji funkcionira kao opći sustav (npr. kao opći kapacitet aktivacije koji predlažu Engle i sur., 1992.), o kojem ovisi učinkovitost koordinacije općih i specifičnih procesa.

Međutim, u ovom je istraživanju razlika između prvog i ostalih klastera najveća u bogatstvu rječnika, a ne u kapacitetu pamćenja. Moguće da su ipak semantički deficiti, kako pretpostavljaju Nation i Snowling (1998.), primaran uzrok problema pri razumijevanju, barem kada zadatak razumijevanja nije vremenski ograničen te kada je tekst dostupan i omogućena je upotreba strategija.

Iako je skupina loših čitača manja od ostalih dobivenih skupina, ona čini $15 \%$ ispitanog uzorka djece, što nije zanemariv postotak. U međunarodnom je ispitivanju pismenosti učenika osmih razreda (PISA, 2006.) oko 15\% djece u Hrvatskoj imalo pismenost na prvoj razini, što bi značilo da su ti učenici sposobni za bazične zadatke razumijevanja, ali ne i za malo zahtjevnije zadatke, poput donošenja jednostavnih zaključaka, razumijevanja dobro definiranoga dijela teksta i primjene prethodnoga znanja za njegovo razumijevanje. Dodatnih 6\% učenika imalo je pismenost nižu i od toga bazičnog nivoa. Rezultate ovog istraživanja nemoguće je direktno uspoređivati s rezultatima PISA-e, ali rezultati obaju istraživanja pokazuju da u završnim razredima osnovne škole postoji dio učenika koji ima problema sa stvaranjem najjednostavnijih zaključaka, čak i kada im je tekst dostupan.

Za razliku od njih, najveći dio učenika u ovom istraživanju, njih $32 \%$, koji čine četvrti klaster, mogu se smatrati dobrim čitačima. Oni čitaju jednako brzo kao učenici s prosječnim razumijevanjem, ali imaju značajno bolje razumijevanje od ostalih skupina, najbogatiji rječnik, najveći raspon kratkoročnoga i radnoga pamćenja te najveću učinkovitost u ozna- 
DRUŠ. ISTRAŽ. ZAGREB GOD. 20 (2011), BR. 1 (111)

STR. $189-210$

RONČEVIĆ ZUBKOVIĆ, B. VJEŠTINA ČITANJA... čavanju fokusnih riječi i nepodudarnih rečenica. Razlika u rasponu radnoga pamćenja između učenika iz toga klastera i učenika iz trećega klastera jest na granici značajnosti. Dobri čitači također percipiraju da iznadprosječno često rabe strategije čitanja, no u tim se varijablama ne razlikuju značajno od učenika iz drugoga klastera.

Taj drugi klaster čini $27 \%$ učenika. Oni imaju prosječno razumijevanje i rječnik, kao i prosječnu učinkovitost određivanja fokusnih riječi i nepodudarnih rečenica. Po tim se varijablama značajno razlikuju od dobrih i loših čitača, ali ne i od učenika iz trećega klastera. Međutim, od učenika iz trećega klastera, koji čini $26 \%$ učenika, razlikuju se u rasponu kratkoročnoga i radnoga pamćenja, koji je kod učenika iz drugoga klastera manji, te po percipiranoj upotrebi strategija čitanja, koja je veća.

S obzirom na to da je raspon radnoga pamćenja značajno veći kod učenika koji se koriste strategijama za upamćivanje riječi u zadatku radnoga pamćenja, provjereno je jesu li učenici iz različitih klastera (koji se razlikuju u rasponu radnoga pamćenja) u različitoj mjeri rabili te strategije. Ustanovljeno je da u svim skupinama postoje učenici koji su se koristili strategijama površinskoga i dubinskoga procesiranja, kao i oni koji nisu primjenjivali nikakve strategije. Među lošim je čitačima najveći postotak učenika koji nije rabio strategije, dok je među dobrim čitačima najveći postotak učenika (77\%) rabio strategije, pa se može zaključiti da je veći raspon radnoga pamćenja djelomično posljedica primjene strategija za upamćivanje riječi. Međutim, razlike u rasponu radnoga pamćenja ne mogu se potpuno objasniti upotrebom strategija, što se jasno vidi iz usporedbe učenika iz drugoga i trećega klastera. Veći raspon radnoga pamćenja kod učenika iz trećega klastera ne proizlazi iz češće upotrebe strategija za upamćivanje riječi, s obzirom na to da je $\mathrm{u}$ tom klasteru čak malo manji postotak učenika $(70 \%)$ rabio strategije u odnosu na drugi klaster $(75,5 \%)$.

Što se tiče vrste strategija koje su učenici koristili, može se vidjeti da je u trećem klasteru dvostruko veći postotak učenika koji su se koristili strategijama dubinskoga procesiranja nego u drugom klasteru. Moguće je da su asocijacije koje su ti učenici stvarali posljedica relativno automatiziranoga procesa stvaranja znakova za doziv, koji se temelje na prethodnom znanju i služe kao pomoć pri upamćivanju ciljnih riječi (Ericsson i Kintsch, 1995.). S druge strane, učenici s malim rasponom u većoj su mjeri rabili strategije površinskoga procesiranja. To je u skladu s rezultatima istraživanja (Turley-Ames i Whitfield, 2003.), koji pokazuju da je učinkovitija strategija kod osoba s malim rasponom radnoga pamćenja ponavljanja riječi nego semantičko kodiranje, s obzirom na to da kod njih aktivacija nevažnih informacija može interferirati s retencijom ciljnih riječi. 
DRUŠ. ISTRAŽ. ZAGREB GOD. 20 (2011), BR. 1 (111)

STR. $189-210$

RONČEVIĆ ZUBKOVIĆ, B. VJEŠTINA ČITANJA...
Međutim, sudeći prema iskazima učenika iz drugoga klastera, iako su u zadatku radnoga pamćenja većinom rabili površinske strategije, prilikom uobičajenoga čitanja rabe i druge strategije, koje uključuju aktivno nadgledanje i regulaciju. Moguće je da u situaciji u kojoj mogu imati dostupan tekst učenici s manjim rasponom radnoga pamćenja primjenjuju kognitivne i metakognitivne strategije. Walczykova teorija kompenzacijskoga kodiranja (Walczyk i sur., 2001.) tako pretpostavlja da osobe s neadekvatnim dekodiranjem i/ili malim rasponom pamćenja mogu donekle kompenzirati ta ograničenja upotrebom raznih strategija za vrijeme čitanja. Naime, rezultati istraživanja (Walczyk i sur., 2007.; Burton i Daneman, 2007.) pokazuju da se ograničenja kapaciteta radnoga pamćenja mogu nadvladati primjenom kompenzacijskih strategijskih ponašanja, kao što su usporavanje čitanja, pogledavanje ili ponovno čitanje već pročitanoga teksta.

Iako nije dobivena razlika u brzini čitanja teksta između drugoga i trećega klastera, treba imati na umu da su se učenici mogli služiti tekstom prilikom odgovaranja na pitanja. Ozuru i sur. (2007.) naglašavaju da pri odgovaranju na pitanja kada je tekst dostupan ključnu ulogu ima upravo učinkovitost upotrebe strategijskoga procesiranja. U ovom istraživanju nije bilo praćeno u kojoj su mjeri učenici zaista rabili strategije kako bi odgovorili na pitanja. Ipak, činjenica da su unatoč manjem rasponu pamćenja učenici iz drugoga klastera jednako uspješno kao učenici iz trećega klastera rješavali zadatke razumijevanja pokazuje vjerojatnost da su se, u skladu s vlastitim samoiskazima, služili strategijama čitanja.

Slične rezultate dobio je i sam Walczyk sa suradnicima (2007.). Autori su klasterskom analizom izdvojili četiri skupine učenika sedmoga razreda koje su se razlikovale s obzirom na uspješnost razumijevanja, kapacitet radnoga pamćenja i upotrebu kompenzacijskih strategija. Tri dobivena klastera vrlo su slična prvom, drugom i četvrtom, dobivenom u ovom istraživanju. Prvu su skupinu činili učenici koji su loše razumjeli, imali najslabiji rezultat na zadatku radnoga pamćenja te su se rijetko koristili strategijama. Drugu su skupinu činili učenici koji su relativno dobro razumjeli, ali su imali nizak rezultat na zadatku radnoga pamćenja te su se koristili kompenzacijskim strategijama. Treću su skupinu činili učenici s najboljim razumijevanjem, najboljim rezultatom na zadatku radnoga pamćenja, koji su se također koristili strategijama. Posljednju skupinu činili su učenici s prosječnim rezultatom na zadatku radnoga pamćenja, koji su neusporedivo najviše rabili strategije i imali su najbolje razumijevanje. Takva skupina nije prepoznata u ovom istraživanju. $\mathrm{S}$ druge strane, Walczyk nije prepoznao skupinu koja bi odgovarala trećem klasteru. 
DRUŠ. ISTRAŽ. ZAGREB GOD. 20 (2011), BR. 1 (111)

STR. $189-210$

RONČEVIĆ ZUBKOVIĆ, B. VJEŠTINA ČITANJA...
No u drugom su istraživanju Walczyk i Griffith-Ross (2007.) prepoznali skupinu fluentnih čitača koji su se rijetko služili strategijama, ali su dobro razumjeli (raspon radnoga pamćenja nije ispitan). Moguće je da je za takve učenike gradivo nedovoljno poticajno da bi ga željeli dublje procesirati, ili da pak nisu upoznati sa strategijama koje mogu koristiti za vrijeme čitanja, ali uspijevaju postići adekvatnu razinu razumijevanja.

Hyönä i suradnici (2002.) služili su se tehnikom praćenja fiksacija pogleda i ustanovili da postoje razlike u načinu procesiranja teksta kod sudionika s različitim rasponima radnoga pamćenja. Razlučili su četiri klastera čitača. Posebno je zanimljiv prvi klaster, koji su činili sudionici s razmjerno velikim rasponom radnoga pamćenja, koji su bili relativno uspješni u kreiranju sažetaka i uspjehu iz materinskoga jezika. Oni su čitali brzo i linearno, bez pauziranja i vraćanja pogleda. Upravo bi ti učenici mogli odgovarati trećem klasteru dobivenom $u$ ovom istraživanju, dakle učenicima čiji su kapaciteti dovoljni da mogu pratiti tekst, ali ne pokazuju veći stupanj angažiranosti. Drugi su klaster činili spori linearni čitači, a treći čitači koji su se često, ali neselektivno, vraćali na već pročitani tekst. Posljednji su klaster činili sudionici s najvećim rasponom radnoga pamćenja, koji su najbolje sažimali tekst i imali najbolji školski uspjeh iz materinskoga jezika. Karakteristika je njihova procesiranja bila da posebnu pozornost pridaju naslovima u tekstu te da se zadržavaju na završecima ulomaka. Ti su učenici, čini se, slični učenicima iz četvrtoga klastera u ovom istraživanju: imaju najveći raspon radnoga pamćenja, a skloni su upotrebi strategija. Vjerojatno upotreba strategija kod tih učenika nije kompenzacijska, nego je odraz njihove veće uključenosti i tendencije k samoreguliranom učenju.

Kako je moguće da različit način procesiranja teksta učenika iz različitih klastera dijelom proizlazi iz motivacije, zanimljivo je obratiti pažnju na spolnu strukturu klastera. Jedino u drugom klasteru ne postoji statistički značajna razlika u broju djevojčica i dječaka. Među najlošijim čitačima ima triput više dječaka nego djevojčica, a treći klaster također u većoj mjeri čine dječaci, kojih ima gotovo dvostruko više nego djevojčica. U klasteru dobrih čitača situacija je obrnuta: taj klaster čini dvostruko više djevojčica nego dječaka.

Prijašnja istraživanja koja su na velikim uzorcima ispitivala spolne razlike $\mathrm{u}$ razumijevanju pri čitanju također su ustanovila statistički značajne razlike koje su upućivale na superioran uradak djevojčica (Chiu i McBride-Chang, 2006.; Lietz, 2006.). Chiu i McBride-Chang (2006.) ustanovile su da je u sve 43 zemlje u kojima se provodilo istraživanje pismenosti PISA postojala veća vjerojatnost da dječaci budu zastupljeni među lošim čitačima u omjeru 2:1. Autorice smatraju da postoji mogućnost da su dječaci čak i u adolescenciji podložniji jezičnim problemima i problemima pismenosti koji proizlaze iz neu- 
DRUŠ. ISTRAŽ. ZAGREB GOD. 20 (2011), BR. 1 (111)

STR. $189-210$

RONČEVIĆ ZUBKOVIĆ, B. VJEŠTINA ČITANJA.. ropsiholoških razloga. Ipak, čini se da je odnos između spola i razumijevanja pri čitanju u najvećoj mjeri uvjetovan interesom za čitanje (Chiu i McBride-Chang, 2006.). Kada se kontrolira efekt ostalih varijabli, doprinos spola objašnjenju varijance razumijevanja spušta se na 1\% (Chiu i McBride-Chang, 2006.; White, 2007.). Važnost interesa i motivacije za čitanje, posebno za dječake, ustanovljena je i u drugim istraživanjima (Ainley i sur., 2002.; Oakhill i Petrides, 2007.).

U ovom su istraživanju učenici u trećem klasteru, koji se većinom sastojao od dječaka, izvještavali o manjoj učestalosti upotrebe strategija, što može govoriti o smanjenoj motivaciji i samoregulaciji. Pretpostavlja se da ti učenici imaju dovoljno kapaciteta za praćenje teksta (granična značajnost razlike $u$ rasponu radnoga pamćenja u odnosu na četvrti klaster), pa mogu uspješno pratiti tekst, razlikovati važne dijelove teksta od nevažnih te postići zadovoljavajuću razinu razumijevanja bez kompenzacijskih ponašanja. Moguće je da bi uz odgovarajuće poučavanje o strategijama, poticanje i dovoljno zanimljive tekstove (Walczyk i Griffith-Ross, 2007.) mogli povećati svoj angažman i doseći razinu razumijevanja koju imaju učenici, većinom djevojčice, iz četvrtoga klastera.

Rezultati ovoga, ali i ostalih, istraživanja pokazuju da je veoma važan način na koji učenici čitaju tekst. S obzirom na to da primjena strategija pri čitanju može u velikoj mjeri unaprijediti vještinu čitanja i čini se čak $u$ određenoj mjeri nadvladati ograničenja radnoga pamćenja, poučavanju strategija čitanja trebali bismo posvetiti posebnu pažnju. To je osobito važno u višim razredima osnovne škole, kada tekstovi postaju sve zahtjevniji i kada se u većoj mjeri otvara mogućnost poučavanja o upotrebi kognitivnih i metakognitivnih strategija (Manset-Williamson i Nelson, 2005.). Rezultati ovog istraživanja također podupiru pretpostavke (npr. Nation i Snowling, 1998.) koje naglašavaju važnost semantičkih vještina za razumijevanje, s obzirom na to što pokazuju da se učenici s najlošijim razumijevanjem u najvećoj mjeri od ostalih učenika razlikuju u bogatstvu rječnika. Istraživanja pokazuju da je i u završnim razredima osnove škole i u srednjoj školi moguće postići značajno poboljšanje razumijevanja upravo obogaćivanjem rječnika (Curtis i Longo, 2001.), što bi trebalo imati na umu u planiranju obrazovnih intervencija koje žele poboljšati razumijevanje.

\section{LITERATURA}

Ainley, M., Hillman, K. i Hidi, S. (2002.), Gender and Interest Processes in Response to Literary Texts: Situational and Individual Interest. Learning and Instruction, 12 (4): 411-428.

Burton, C. i Daneman, M. (2007.), Compensating for a Limited Working Memory Capacity during Reading: Evidence from Eye Movements. Reading Psychology, 28 (2): 163-186. 
DRUŠ. ISTRAŽ. ZAGREB GOD. 20 (2011), BR. 1 (111)

STR. 189-210

RONČEVIĆ ZUBKOVIĆ, B.: VJEŠTINA ČITANJA...
Cain, K. i Oakhil, J. (2006.), Profiles of Children with Specific Reading Comprehension Difficulties. British Journal of Educational Psychology, 76 (4): 683-696.

Cain, K., Oakill, J. i Bryant, P. E. (2004.a), Children's Reading Comprehension Ability: Concurrent Prediction by Working Memory, Verbal Ability, and Component Skills. Journal of Educational Psycho$\log y, 96$ (1): 31-42.

Cain, K., Oakhill, J. i Lemmon, K. (2004.b), Individual Differences in the Inference of Word Meanings from Context: The Influence of Reading Comprehension, Vocabulary Knowledge, and Memory Capacity. Journal of Educational Psychology, 96 (4): 671-681.

Cain, K., Oakhill, J. i Elbro, C. (2003.), The Ability to Learn New Word Meanings from Context by School-Age Children with and Without Language Comprehension Difficulties. Journal of Child Language, 30 (3): 681-694.

Cain, K., Oakhill, J. V., Barnes, M. A. i Bryant, P. E. (2001.), Comprehension Skill, Inference-Making Ability, and their Relation to Knowledge. Memory and Cognition, 29 (6): 850-859.

Chiu, M. M. i McBride-Chang, C. (2006.), Gender, Context, and Reading: A Comparison of Students in 43 Countries. Scientific Studies of Reading, 10 (4): 331-362.

Cromley, J. G. (2005.), Reading Comprehension Component Processes in Early Adolescence. Dissertation Abstracts International, 66, 2100A.

Curtis, M. E. i Longo, A. M. (2001.), Teaching Vocabulary to Adolescents to Improve Comprehension, Reading Online, 5. http://www. readingonline.org/articles/art index.asp?HREF $=$ curtis/index.html (10. 5. 2008.)

Didović, M. i Kolić-Vehovec, S. (2009.), Različiti aspekti poznavanja rječnika i razumijevanje teksta kod učenika osnovne škole. Psihologijske teme, 18: 99-117.

Dixon, P., LeFevre, J. i Twilley, L. C. (1988.), Word Knowledge and Working Memory as Predictors of Reading Skill. Journal of Educational Psychology, 80 (4): 465-472.

Ehrlich, M.-F., Remond, M. i Tardieu, H. (1999.), Processing of Anaphoric Devices in Young Skilled and Less Skilled Comprehenders: Differences in Metacognitive Monitoring. Reading and Writing: An Interdisciplinary Journal, 11 (1): 29-63.

Engle, R. W., Cantor, J. i Carullo, J. J. (1992.), Individual Differences in Working Memory and Comprehension: A Test of Four Hypotheses. Journal of Experimental Psychology: Learning, Memory, and Cognition, 18 (5): 972-992.

Ericsson, K. A. i Kintsch, W. (1995.), Long-Term Working Memory. Psychological Review, 102 (2): 211-245.

Fletcher, J. M., Shaywitz, S. E., Shankweiler, D. P., Katz, L., Liberman, I. Y., Steubing, K. K., Francis, D. J., Fowler, A. E. i Shaywitz, B. A. (1994.), Cognitive Profiles of Reading Disability: Comparisons of Discrepancy and Low Achievement Definitions. Journal of Educational Psychology, 86 (1): 6-23.

Francis, D. J., Shaywitz, S. E., Stuebing, K. K., Shaywitz, B. A. i Fletcher, J. M. (1996.), Developmental Lag Versus Deficit Models of 
DRUŠ. ISTRAŽ. ZAGREB GOD. 20 (2011), BR. 1 (111)

STR. $189-210$

RONČEVIĆ ZUBKOVIĆ, B. VJEŠTINA ČITANJA...
Reading Disability: A Longitudinal, Individual Growth Curves Analysis. Journal of Educational Psychology, 88 (1): 3-17.

Gathercole, S. E. (1999.), Cognitive Approaches to the Development of Short-Term Memory. Trends in Cognitive Sciences, 3 (11): 410-419.

Hershel, T. M. (1963.), The 20th Yearbook of the National Council on Measurement in Education, Ann Arbor, MI: SGSR.

Hyönä, J., Lorch, R. F. i Kaakinen, J. K. (2002.), Individual Differences in Reading to Summarize Expository Text: Evidence from Eye Fixation Patterns. Journal of Educational Psychology, 94 (1): 44-55.

Kolić-Vehovec, S. (1994.), Kognitivni čimbenici vještine čitanja. Godišnjak Odsjeka za psihologiju, 3: 115-128.

Kolić-Vehovec, S. i Bajšanski, I. (2001.), Konstrukcija upitnika strategijskog čitanja. Psihologijske teme, 10: 51-62.

Kolić-Vehovec, S. i Bajšanski, I. (2006.), Dobne i spolne razlike u nekim vidovima metakognicije i razumijevanja pri čitanju. Društvena istraživanja, 15 (6): 1005-1027.

Lietz, P. (2006.), A Meta-Analysis of Gender Differences in Reading Achievement at the Secondary School Level. Studies in Educational Evaluation, 32 (4): 317-344.

Manset-Williamson, G. i Nelson, J. M. (2005.), Balanced, Strategic Reading Instruction for Upper Elementary and Middle School Students with Reading Disabilities: A Comparative Study of Two Approaches. Learning Disability Quarterly, 28 (1): 59-74.

Moguš, M., Bratanić, M. i Tadić, M. (1999.), Hrvatski čestotni rječnik, Zagreb: Školska knjiga.

Morris, R. D., Stuebing, K. K., Fletcher, J. M., Shaywitz, S. E., Lyon, G. R., Shankweiler, D. P., Katz, L., Francis, D. J. i Shaywitz, B. A. (1998.), Subtypes of Reading Disability: Variability around a Phonological Core. Journal of Educational Psychology, 90 (3): 347-373.

Nation, K. i Snowling, M. J. (1998.), Semantic Processing and the Development of Word-Recognition Skills: Evidence from Children with Reading Comprehension Difficulties. Journal of Memory and Language, 39 (1): 85-101.

Oakhill, J., Hartt, J. i Samols, D. (2005.), Levels of Comprehension Monitoring and Working Memory in Good and Poor Comprehenders. Reading and Writing, 18 (7-9): 657-686.

Oakhill, J. V. i Petrides, A. (2007.), Sex Differences in the Effects of Interest on Boys' and Girls' Reading Comprehension. British Journal of Psychology, 98 (2): 223-236.

Osaka, M., Nishizaki, Y., Komori, M. i Osaka, N. (2002.), Effect of Focus on Verbal Working Memory: Critical Role of the Focus Word in Reading. Memory and Cognition, 30 (4): 562-571.

Ozuru, Y., Best, R., Bell, C., Witherspoon, A. i McNamara, D. (2007.), Influence of Question Format and Text Availability on the Assessment of Expository Text Comprehension. Cognition and Instruction, 25 (4): 399-438. Perfetti, C. A. (1985), Reading Ability, New York: Oxford University Press. PISA (2006.), Science Competencies for Tomorrow's World, Executive summary, OECD. http://www.oecd.org/dataoecd/15/13/39725224.pdf (17. 4. 2008 .) 
DRUŠ. ISTRAŽ. ZAGREB GOD. 20 (2011), BR. 1 (111)

STR. 189-210

RONČEVIĆ ZUBKOVIĆ, B.: VJEŠTINA ČITANJA...
Rasinski, T. V., Padak, N. D., McKeon, C. A. Wilfong, L. G., Friedauer, J. A. i Heim, P. (2005.), Is Reading Fluency a Key for Successful High School Reading? Journal of Adolescent and Adult Literacy, 49 (1): 22-29.

Shankweiler, D. i Crain, S. (1986.), Language Mechanisms and Reading Disorder: A Modular Approach. Cognition, 24 (1-2): 139-168.

Siegel, L. S. (1994.), Working Memory and Reading: A Life-Span Perspective. International Journal of Behavioral Development, 17 (1): 109-124.

Swanson, H. L. i Alexander, J. (1997.), Cognitive Processes as Predictors of Word Recognition and Reading Comprehension in Learning Disabled and Skilled Readers: Revisiting the Specificity Hypothesis. Journal of Educational Psychology, 89 (1): 128-158.

Swanson, H. L., Howard, C. B. i Sáez, L. (2006.), Do Different Components of Working Memory Underlie Different Subgroups of Reading Disabilities? Journal of Learning Disabilities, 39 (3): 252-269.

Toličič, I. i Zorman, L. (1977.), Okolje in uspešnost učencev, Ljubljana: DZS. Turley-Ames, K. J. i Whitfield, M. M. (2003.), Strategy Training and Working Memory Task Performance. Journal of Memory and Language, 49 (4): 446-468.

Walczyk, J. J. i Griffith-Ross, D. A. (2007.), How Important is Reading Skill Fluency for Comprehension? The Reading Teacher, 60 (6): 560-569.

Walczyk, J. J., Marsiglia, C. S., Bryan, K. S. i Naquin, P. J. (2001.), Overcoming Inefficient Reading Skills. Journal of Educational Psychology, 93 (4): 750-757.

Walczyk, J. J., Wei, M., Grifith-Ross, D. A., Goubert, S. E., Cooper, A. L. i Zha, P. (2007.), Development of the Interplay between Automatic Processes and Cognitive Resources in Reading. Journal of Educational Psychology, 99 (4): 867-887.

White, B. (2007.), Are Girls Better Readers than Boys? Which Boys? Which Girls? Canadian Journal of Education, 30 (2): 554-581.

Williams, J. P., Taylor, M. B. i Ganger, S. (1981.), Text Variations at the Level of the Individual Sentence and the Comprehension of Simple Expository Paragraphs. Journal of Educational Psychology, 73 (6): 851-865. Yovanoff, P., Duesbery, L., Alonzo, J. i Tindal, G. (2005.), Grade-Level Invariance of a Theoretical Causal Structure Predicting Reading Comprehension with Vocabulary and Oral Reading Fluency. Educational Measurement: Issues and Practice, 24 (3): 4-12.

\section{Reading Skill in Early Adolescence: Student Profiles}

Barbara RONČEVIĆ ZUBKOVIĆ

Faculty of Arts and Sciences, Rijeka

The aim of this study was to explore whether homogenous profiles of students could be differentiated based on their comprehension level, reading speed, vocabulary, short-term and working memory spans, and use of reading strategies. One hundred eighty six seventh-graders participated in the study (98 
DRUŠ. ISTRAŽ. ZAGREB GOD. 20 (2011), BR. $1(111)$

STR. $189-210$

RONČEVIĆ ZUBKOVIĆ, B.: VJEŠTINA ČITANJA.. boys and 88 girls). Comprehension was assessed for three short texts, and reading speed for one of these. Students also completed vocabulary test, strategic reading questionnaire and short-term and working memory tasks. The ability to detect focus words in the sentences and inappropriate sentences in the text was also tested. Cluster analysis yielded four distinct student profiles. The first cluster consists of poor readers who score below the average in all the tasks. The fourth cluster consists of good readers who score above the average in all the tasks, except for average reading speed. The second and the third cluster consist of students of average comprehension, reading speed, vocabulary and efficiency in detecting focus words and inappropriate sentences. The students from the second cluster have significantly smaller short-term and working memory spans than students from the third cluster, but they report more frequent use of reading strategies. These results are in line with theories emphasizing the importance of compensatory strategies in overcoming working memory limitations (Walczyk et al., 2001; 2007).

Keywords: reading, comprehension, strategies, working memory

\section{Lesefähigkeit in der Frühadoleszenz: Schülerprofile}

\author{
Barbara RONČEVIĆ ZUBKOVIĆ \\ Philosophische Fakultät, Rijeka
}

In dieser Arbeit soll untersucht werden, ob im Hinblick auf Leseverständnis und Lesegeschwindigkeit, Wortschatzreichtum, die Belastbarkeit des Kurzzeit- und des Arbeitsgedächtnisses sowie hinsichtlich des Einsatzes erfolgreicher Lesestrategien in der Schülerpopulation homogene Gruppierungen bzw. bestimmte Schülerprofile erkennbar sind. An der Untersuchung nahmen 186 Siebtklässler* teil (98 Jungen und 88 Mädchen). Geprüft wurde das Leseverständnis von drei kurzen Texten, wobei im Falle eines der Texte auch die Lesegeschwindigkeit gemessen wurde. Des Weiteren lösten die Schüler und Schülerinnen einen Wortschatztest, einen Fragebogen zur Ermittlung strategischer Lesefähigkeiten sowie Aufgaben zur Prüfung des Kurzzeit- und des Arbeitsgedächtnisses; außerdem sollten sie Fokuswörter in Sätzen sowie in einem Text unpassende Sätze erkennen. Eine Clusteranalyse brachte klar vier Schülerprofile (Gruppierungen) zum Vorschein. Der erste Cluster besteht aus schlechten Lesern, die bei allen Aufgaben Resultate unterhalb der Durchschnittswerte erzielten. Der vierte Cluster besteht aus guten Schülern mit überdurchschnittlichen Ergebnissen bei allen

* Schüler der Grundschule: Die Grundschule in Kroatien umfasst die Klassen 1 bis 8 (Anm. d. Übers.). 
DRUŠ. ISTRAŽ. ZAGREB GOD. 20 (2011)

BR. 1 (111)

STR. $189-210$

RONČEVIĆ ZUBKOVIĆ, B.: VJEŠTINA ČITANJA...
Aufgaben; lediglich die Lesegeschwindigkeit enwies sich als durchschnittlich. Der zweite und dritte Cluster besteht aus Schülern mit durchschnittlichem Resultaten hinsichtlich Leseverständnis, Lesegeschwindigkeit und Wortschatzreichtum sowie Ermittlung von Fokuswörtern und unpassenden Sätzen. Die Schüler des zweiten Clusters weisen, im Vergleich mit Schülern des dritten Clusters, eine wesentlich geringere Belastbarkeit sowohl des Kurzzeit- als auch des Arbeitsgedächtnisses auf, doch berichten sie vom wiederholten Einsatz verschiedener Lesestrategien. Die gewonnenen Ergebnisse konnten Theorien bestätigen, denen zufolge kompensatorische Strategien dabei helfen können, bestimmte Defizite in der Belastbarkeit des Arbeitsgedächtnisses zu überbrücken (Walczyk et al., 2001; 2007).

Schlüsselbegriffe: Lesen, Verstehen, Strategien, Arbeitsgedächtnis 